\title{
Projected Prevalence of Inadequate Nutrient Intakes in Europe
}

\author{
Blanca Roman Viñas ${ }^{a}$ Lourdes Ribas Barba ${ }^{a}$ Joy Ngo ${ }^{a}$ Mirjana Gurinovic ${ }^{c}$ \\ Romana Novakovic ${ }^{c}$ Adriënne Cavelaars ${ }^{d}$ Lisette C.P.G.M. de Groot ${ }^{d}$ \\ Pieter van't Veer ${ }^{d}$ Christophe Matthys ${ }^{\mathrm{e}} \quad$ Lluís Serra Majem $^{\mathrm{a}}{ }^{\mathrm{b}}$ \\ ${ }^{a}$ Community Nutrition Research Centre of the Nutrition Research Foundation, University of Barcelona Science Park,

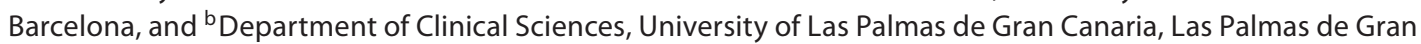 \\ Canaria, Spain; ' Department of Nutrition and Metabolism, Institute for Medical Research, University of Belgrade, \\ Belgrade, Serbia; ${ }^{d}$ Division of Human Nutrition, Wageningen University and Research Centre, Wageningen,

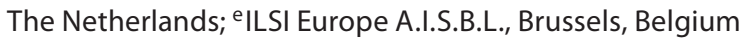

\section{Key Words}

Nutrient intake adequacy - Europe - Estimated average

requirement cut point $\cdot$ EURRECA $\cdot$ Adults · Elderly

\begin{abstract}
Background: The purpose of this study was to analyze the prevalence of nutrient intake inadequacy in Europe, applying the Nordic Nutritional Recommendations in the context of the EURRECA Network of Excellence. Methods: Nutrient data was obtained from the European Nutrition and Health Report II. Those nutritional surveys using a validated food frequency questionnaire or diet history and a food diary/ register with at least 7 days of registers or with an adjustment for intraindividual variability were included. The nutrients analyzed were: vitamin $C$, vitamin $D$, vitamin $B_{12}$, folic acid, calcium, iron, zinc, selenium, copper, and iodine. The estimated average requirement cut point was applied to estimate inadequacy. The Nordic and Institute of Medicine nutrient recommendations were used as references. Results: The mean prevalence of inadequacy was below $11 \%$ for zinc, iron, and vitamin $B_{12}$ (only in the elderly), and it was $11-20 \%$ for copper in adults and the elderly and for vitamin $B_{12}$ in adults and vitamin $C$ in the elderly. The prevalence was above $20 \%$ for vitamin D, folic acid, calcium, selenium, and
\end{abstract}

iodine in adults and the elderly and for vitamin $C$ in adults. Conclusions: Vitamin C, vitamin D, folic acid, calcium, selenium, and iodine were the nutrients showing a higher prevalence of inadequate intakes in Europe.

Copyright $\odot 2011$ S. Karger AG, Basel

\section{Introduction}

The EURopean micronutrient RECommendations Aligned (EURRECA; www.eurreca.org) Network of Excellence is working to provide an evidence-based framework for establishing micronutrient requirements [1]. A key focus of the Network is to identify vulnerable population groups who are at greater nutritional risk, with an analysis of nutrient adequacy assessment being a targeted activity [2,3]. Tabbachi et al. [3] reviewed the methods used to estimate nutrient intake adequacy in nutrition surveys. Al-Tahan et al. [4] reviewed the studies evaluating vitamin B intake in European adolescents. Moreover, Fabian and Elmadfa [5] used the information of the European Nutrition and Health Report I to provide an overview of the micronutrient inadequacies in the European elderly. They all found large discrepancies in the prevalence of nutrient intake inadequacy across Europe due in

\section{KARGER \\ Fax +41613061234 \\ E-Mail karger@karger.ch}

www.karger.com
(C) 2011 S. Karger AG, Basel

0250-6807/11/0594-0084\$38.00/0

Accessible online at:

www.karger.com/anm
Lluís Serra Majem

Nutrition Research Foundation, Barcelona Science Park

University of Barcelona, C/ Baldiri i Reixac 4-8

ES-08028 Barcelona (Spain)

Tel. +3493 403 4541, E-Mail lserra@ dcc.ulpgc.es 
part to the different methodologies for dietary intake and analysis that were applied as well as the nutritional recommendations used.

Comparing data on nutrient intake deficiencies and excesses across Europe is a task hampered by difficulties. Study methodologies and purposes vary from country to country. Not all European countries have conducted representative nutritional surveys at the national level, with some of them being only regional or local. In addition, the assessment of food intake varies from country to country and the purpose of the survey may not include the evaluation of nutritional status. Several efforts and expert appeals have been made that address the need to share a common methodology when conducting nutritional surveys $[6,7]$. As these difficulties have been recognized, the need and methodology for the harmonization of pan-European nutrition surveillance has been addressed in the EC-funded EFCOSUM [7] and EFCOVAL [8] consortia and is incorporated into the EC policy [9]. However, for the time being, the comparison of nutrient intake and status across Europe has to rely on existing information. The objective of this study was to analyze the prevalence of inadequate intakes of a number of micronutrients in adult and elderly populations utilizing the most representative European data and applying the estimated average requirement (EAR) cut point and the Nordic Nutritional Recommendations.

\section{Subjects and Methods}

The data included were obtained from the European Nutrition and Health Report II (ENHRII) and the ILSI Europe Addition of Nutrients to Food Task Force report, based on the search strategy proposed by Blanquer et al. [10]. The ENHRII was a European funded project [11] with 25 participating countries (Austria, Belgium, Cyprus, Czech Republic, Denmark, Estonia, Finland, France, Germany, Greece, Hungary, Ireland, Italy, Latvia, Lithuania, Luxembourg, Norway, Poland, Portugal, Romania, Slovenia, Spain, Sweden, The Netherlands, and the UK). The ILSI Europe report provided information on the risk of excess intake in representative European countries [12].

\section{Methods}

The EAR cut point was applied to estimate the prevalence of nutrient intake adequacy [13]. To apply this method, information on usual intakes is needed in order to attenuate intraindividual variability [14]. When using diet recalls or registers, the usual intake is estimated by applying statistical methods $[15,16]$. In the case of food frequency questionnaire (FFQ) administration, validation of the instrument is needed [17-19]. The nutritional studies represented by both European projects had different methodologies not only with regard to the food assessment method but also in relation to data analysis and the approach for presenting the re- sults. Only those nutritional surveys using a validated FFQ or having applied a method of adjustment for individual variability were considered. Due to the limited number of studies using such methodologies, those studies that did not adjust for individual variability but had at least 7 days of registered intake were also included [20]. Only studies with a sample size of at least 100 individuals were considered for the analysis, as recommended by Murphy et al. [21].

Following the EURRECA research [22], the Nordic Recommendations were used as the reference values for comparison [23]. When no EAR was defined for the nutrient under study (vitamin $\mathrm{D}$ and calcium), the EAR defined by the Institute of Medicine (IOM) was used as a cut-off point [24].

The nutrients under study were those selected as priority micronutrients by the EURRECA project [25]: vitamin C, vitamin $\mathrm{D}$, vitamin $\mathrm{B}_{12}$, folic acid, iron, zinc, calcium, selenium, copper, and iodine.

The population groups analyzed were: adults (aged 19-64 years) and the elderly (aged more than 64 years).

To apply the EAR cut point, the requirement distribution for the nutrient under study must follow a symmetrical distribution. As the iron requirements in women of childbearing age are skewed, this population age group was excluded. For the remaining nutrients, a normal intake distribution was assumed.

As the information available consisted only of published data (i.e. mean and SD of the nutrient under study), the EAR cut point was calculated as follows: $z=(x-\mu) / S D$, with $x$ being the EAR and $\mu$ the nutrient mean intake, and by calculating the area below the curve for the $\mathrm{z}$ value in a normal distribution of mean $=0$ and $\mathrm{SD}=1$. The result was then expressed as a percent.

Given that not all countries had data for all ten micronutrients, a comparison was made for the countries having the most data for the same micronutrients of interest. Those countries were ranked according to the following ratio: number of nutrients with a prevalence of intake inadequacy above $20 \%$ of the population/total number of nutrients.

\section{Results}

The nutritional surveys were checked for compliance with the inclusion criteria. As the ENHRII contained more recent data, all nutrient intake data were obtained from such report except for the information from The Netherlands. As the study representing The Netherlands in the ENHRII (Dutch National Food Survey 1997-1998) was not adjusted for individual variability, the data was obtained from the Flynn report (Dutch National Food Survey 2003) which met the inclusion criteria [12]. For the UK, the nutritional information provided in the ENHRII represented a low income sample. As such, the data was obtained from the European Nutrition and Health Report I [26].

The following countries had studies that did not comply with the quality criteria: Austria [a single 24-hour recall (HR) for the adults and a 3-day dietary record (DR) for the elderly], Cyprus and Luxembourg (no data for the population groups analyzed), the Czech Republic, Esto- 
Table 1. Vitamin C intake (mg/day) and prevalence of inadequate intake (\% population below EAR) in Europe by gender and population group

\begin{tabular}{|c|c|c|c|c|c|c|c|c|c|}
\hline \multirow{2}{*}{$\begin{array}{l}\text { Coun- } \\
\text { try }\end{array}$} & \multirow{2}{*}{ Study } & \multirow[t]{2}{*}{ Study year } & \multirow{2}{*}{$\begin{array}{l}\text { Food intake } \\
\text { method }\end{array}$} & \multicolumn{3}{|c|}{ Males (EAR $=60 \mathrm{mg} /$ day) } & \multicolumn{3}{|c|}{ Females $(\mathrm{EAR}=50 \mathrm{mg} /$ day $)$} \\
\hline & & & & $\mathrm{n}$ & mean $\pm S D$ & $\begin{array}{l}\text { \% below } \\
\text { EAR }\end{array}$ & $\mathrm{n}$ & mean $\pm S D$ & $\begin{array}{l}\text { \% below } \\
\text { EAR }\end{array}$ \\
\hline \multicolumn{10}{|c|}{ Adults (age 19-64 years) } \\
\hline $\mathrm{BE}$ & Belgian Food Consumption Survey [27] & 2004 & adj $2 \times 24 \mathrm{HR}$ & n.a. & $88 \pm 36$ & 21.8 & n.a. & $92 \pm 44$ & 17.0 \\
\hline $\mathrm{DE}$ & German National Nutrition Survey II [31-33] & 2005-2007 & $\mathrm{DH}$ & 4,912 & $153 \pm 106$ & 19.0 & 6,016 & $153 \pm 84$ & 11.0 \\
\hline DK & Danish National Survey of Dietary Habits and PA [28] & 2000-2002 & $7 \mathrm{dDR}$ & 1,283 & $102 \pm 56$ & 22.7 & 1,486 & $107 \pm 61$ & 17.5 \\
\hline ES & ENCAT 2002-2003 [36-38] & $2002-2003$ & adj $2 \times 24 \mathrm{HR}$ & 706 & $97 \pm 37$ & 15.9 & 875 & $108 \pm 42$ & 8.4 \\
\hline FI & National FINDIET 2007 Survey $[29,30]$ & 2007 & adj $48 \mathrm{HR}$ & 730 & $98 \pm 88$ & 33.3 & 846 & $118 \pm 82$ & 20.3 \\
\hline GR & EPIC study $[11]$ & 1994-1999 & FFQ & 500 & $146 \pm 130$ & 25.4 & 451 & $145 \pm 120$ & 21.4 \\
\hline IR & SLAN 2007 [34] & 2007 & FFQ & 662 & $116 \pm 223$ & 40.1 & 717 & $108 \pm 183$ & 37.6 \\
\hline IT & INN-CA Study [35] & 1994-1996 & $7 \mathrm{dDR}$ & 660 & $122 \pm 65$ & 17.0 & 801 & $113 \pm 58$ & 13.9 \\
\hline NO & Norkost 1997 [11] & 1997 & FFQ & 1,050 & $140 \pm 95$ & 20.0 & 1,146 & $149 \pm 88$ & 13.0 \\
\hline PT & EpiPorto [11] & 1999-2003 & FFQ & 917 & $116 \pm 54$ & 15.0 & 1,472 & $131 \pm 63$ & 9.9 \\
\hline SE & Riksmaten 1997-1998 [39] & 1997-1998 & $7 \mathrm{dDR}$ & 517 & $79 \pm 45$ & 33.6 & 575 & $90 \pm 50$ & 21.2 \\
\hline UK & Health Survey for England [42] & $2000-2001$ & $7 \mathrm{dDR}$ & 219 & $84 \pm 66$ & 36.0 & 210 & $85 \pm 85$ & 34.0 \\
\hline \multicolumn{10}{|c|}{ Elderly (age $>64$ years) } \\
\hline $\mathrm{BE}$ & Belgian Food Consumption Survey [27] & 2004 & adj $2 \times 24 \mathrm{HR}$ & n.a. & $91 \pm 43$ & 23.5 & n.a. & $87 \pm 44$ & 20.0 \\
\hline $\mathrm{DE}$ & German National Nutrition Survey II [31-33] & 2005-2007 & $\mathrm{DH}$ & 1,469 & $142 \pm 70$ & 12.1 & 1,562 & $148 \pm 81$ & 11.3 \\
\hline DK & Danish National Survey of Dietary Habits and PA [28] & $2000-2002$ & $7 \mathrm{dDR}$ & 165 & $95 \pm 52$ & 25.0 & 164 & $115 \pm 67$ & 16.6 \\
\hline ES & Catalan Nutrition Survey [36-38] & $2002-2003$ & $\operatorname{adj} 2 \times 24 \mathrm{HR}$ & 163 & $126 \pm 50$ & 9.3 & 179 & $115 \pm 38$ & 4.4 \\
\hline FI & National FINDIET 2007 Survey $[29,30]$ & 2007 & adj 48 HR & 229 & $92 \pm 72$ & 32.8 & 234 & $97 \pm 68$ & 24.5 \\
\hline NO & Norkost 1997 [11] & 1997 & FFQ & 176 & $139 \pm 81$ & 16.5 & 176 & $160 \pm 87$ & 10.3 \\
\hline PT & EpiPorto [11] & 1999-2003 & FFQ & 246 & $121 \pm 57$ & 14.2 & 339 & $118 \pm 57$ & 11.6 \\
\hline
\end{tabular}

$\mathrm{EAR}=$ Estimated average requirement; $\mathrm{BE}=$ Belgium; $\mathrm{DE}=$ Germany; $\mathrm{DK}=$ Denmark; $\mathrm{ES}=$ Spain FI = Finland; GR = Greece; $\mathrm{IR}=\mathrm{Ireland} ; \mathrm{IT}=$ Italy; $\mathrm{NO}=$ Norway; $\mathrm{PT}=$ Portugal; $\mathrm{SE}=$ Sweden UK = United Kingdom; adj = adjusted for intraindividual variability; $\mathrm{HR}=\mathrm{hour}$ recall; $\mathrm{DH}=\mathrm{diet}$ history; $\mathrm{dDR}=$ days dietary record; $\mathrm{FFQ}=$ food frequency questionnaire; .a. $=$ not available.

nia, Latvia, Lithuania and Poland (a single $24 \mathrm{HR}$ ), Hungary (3-day DR), Romania (no information on the food intake method), The Netherlands (2-day DR for the elderly), and the UK (4-day DR for the elderly). For the elderly group, the nutritional surveys from Sweden and Italy (for certain micronutrients in the male population) were not included (sample size lower than 100 individuals).

The countries that had studies with suitable data for the adults were: Belgium (Belgian Food Consumption Survey, 2004) [27], Denmark (Danish National Survey of Dietary Habits and Physical Activity, 2000-2002) [28], Finland (National FINDIET 2007 Survey) [29, 30], Germany (German National Nutritional Survey II, 20052007) [31-33], Greece (Greek EPIC study, 1994-1999) [11], Ireland (SLAN, 2007) [34], Italy (INN-CA study) [35], Norway (Norkost, 1997) [11], Portugal (EPI Porto study, 1999-2003) [11], Spain (ENCAT 2002-2003) [36-38], Sweden (Riksmaten 1997-1998) [39], The Netherlands (Dutch National Food Consumption Survey, 2003) [40, 41], and the UK (Health Survey for England, 2001-2002) [42], and for the elderly group: Belgium (Belgian Food Consumption Survey, 2004) [27], Denmark (Danish National Survey of Dietary Habits and Physical Activity, 2000-2002) [28], Finland (National FINDIET 2007 Survey) [29, 30], Germany (German National Nutritional Survey II, 20052007) [31-33], Italy (INN-CA study) [35], Norway (Norkost, 1997) [11], Portugal (EPI Porto study, 1999-2003) [11], and Spain (ENCAT 2002-2003) [36-38] [11].

The food intake data were obtained from food diaries in most of the countries. The data from The Netherlands (two $24 \mathrm{HR}$, only in the adult population group), Belgium (two $24 \mathrm{HR}$ ), Finland (a $48 \mathrm{HR}$ ), and Spain (two $24 \mathrm{HR}$ ) were obtained applying an adjustment for intra-individual variability. The studies from Italy, Denmark, the UK, and Sweden used 7-day DR. The following countries used a validated FFQ: Greece for the adult group [43], Ireland [44], Norway [45], and Portugal [46, 47]. Germany used a validated diet history (DISHES 98) [48].

The nutrient intake data included food supplement data in the nutritional surveys of Norway and Ireland (adults). None of the data provided excluded underreporters. 
Table 2. Vitamin D ( $\mu \mathrm{g} /$ day) intake and prevalence of inadequate intake (\% population below EAR) in Europe by gender and population group

\begin{tabular}{|c|c|c|c|c|c|c|c|c|c|}
\hline \multirow{2}{*}{\multicolumn{2}{|c|}{$\begin{array}{l}\text { Coun- Study } \\
\text { try }\end{array}$}} & \multirow[t]{2}{*}{ Study year } & \multirow{2}{*}{$\begin{array}{l}\text { Food intake } \\
\text { method }\end{array}$} & \multicolumn{3}{|c|}{ Males $(\mathrm{EAR}=10 \mu \mathrm{g} /$ day $)$} & \multicolumn{3}{|c|}{ Females $(\mathrm{EAR}=10 \mu \mathrm{g} /$ day $)$} \\
\hline & & & & $\mathrm{n}$ & mean $\pm S D$ & $\begin{array}{l}\text { \% below } \\
\text { EAR }\end{array}$ & $\mathrm{n}$ & mean $\pm S D$ & $\begin{array}{l}\text { \% below } \\
\text { EAR }\end{array}$ \\
\hline \multicolumn{10}{|c|}{ Adults (age 19-64 years) } \\
\hline $\mathrm{DE}$ & German National Nutrition Survey II [31-33] & 2005-2007 & DH & 4,912 & $3.8 \pm 3.6$ & 95.7 & 6,016 & $2 \pm 1.3$ & 100.0 \\
\hline DK & Danish National Survey of Dietary Habits and PA [28] & 2000-2002 & $7 \mathrm{dDR}$ & 1,283 & $3.6 \pm 2.8$ & 98.9 & 1,486 & $2.8 \pm 2.3$ & 99.9 \\
\hline ES & ENCAT 2002-2003 [36-38] & $2002-2003$ & adj $2 \times 24 \mathrm{HR}$ & 706 & $1.6 \pm 0.8$ & 100.0 & 875 & $1.2 \pm 0.6$ & 100.0 \\
\hline FI & National FINDIET 2007 Survey $[29,30]$ & 2007 & adj $48 \mathrm{HR}$ & 730 & $7.1 \pm 5.7$ & 69.5 & 846 & $5.2 \pm 4.2$ & 87.3 \\
\hline IR & SLAN $2007[34]$ & 2007 & FFQ & 662 & $3.7 \pm 3.4$ & 96.8 & 717 & $3.7 \pm 8.7$ & 76.6 \\
\hline IT & INN-CA Study [35] & 1994-1996 & $7 \mathrm{dDR}$ & 660 & $3.5 \pm 2.3$ & 99.8 & 801 & $2.8 \pm 1.8$ & 100.0 \\
\hline NE & Dutch National Food Consumption Survey $2003[40,41]$ & 2003 & $2 \times 24 \mathrm{HR}$ & 352 & $3.7 \pm 1.5$ & 100.0 & 398 & $2.7 \pm 1.5$ & 100.0 \\
\hline NO & Norkost 1997 [11] & 1997 & FFQ & 1,050 & $10.9 \pm 10.7$ & 46.6 & 1,146 & $10.1 \pm 9.1$ & 49.6 \\
\hline PT & EpiPorto [11] & $1999-2003$ & FFQ & 917 & $3.6 \pm 1.7$ & 100.0 & 1,472 & $3.5 \pm 1.6$ & 100.0 \\
\hline SE & Riksmaten 1997-1998 [39] & $1997-1998$ & $7 \mathrm{dDR}$ & 517 & $6.1 \pm 2.7$ & 92.6 & 575 & $4.8 \pm 1.9$ & 99.7 \\
\hline UK & Health Survey for England [42] & $2000-2001$ & $7 \mathrm{dDR}$ & 219 & $4.1 \pm 3.2$ & 96.7 & 210 & $2.7 \pm 2.0$ & 100.0 \\
\hline \multicolumn{10}{|c|}{ Elderly (age $>64$ years) } \\
\hline $\mathrm{DE}$ & German National Nutrition Survey II [31-33] & 2005-2007 & $\mathrm{DH}$ & 1,469 & $4.4 \pm 4.1$ & 91.4 & 1,562 & $3.4 \pm 2.8$ & 99.1 \\
\hline $\mathrm{DK}$ & Danish National Survey of Dietary Habits and PA [28] & $2000-2002$ & $7 \mathrm{dDR}$ & 165 & $3.9 \pm 3.1$ & 97.5 & 164 & $3.1 \pm 2.1$ & 99.9 \\
\hline ES & ENCAT 2002-2003 [36-38] & $2002-2003$ & $\operatorname{adj} 2 \times 24 \mathrm{HR}$ & 163 & $0.7 \pm 0.1$ & 100.0 & 179 & $0.7 \pm 0.1$ & 100.0 \\
\hline FI & National FINDIET 2007 Survey $[29,30]$ & 2007 & adj $48 \mathrm{HR}$ & 229 & $9 \pm 8.2$ & 54.9 & 234 & $6.5 \pm 4.6$ & 77.7 \\
\hline IR & SLAN 2007 [34] & 2007 & FFQ & 580 & $3.5 \pm 2.1$ & 99.9 & 742 & $3.2 \pm 1.9$ & 100.0 \\
\hline IT & INN-CA Study [35] & 1994-1996 & $7 \mathrm{dDR}$ & 60 & $2.5 \pm 1.7$ & 100.0 & 107 & $2.4 \pm 1.8$ & 100.0 \\
\hline NO & Norkost 1997 [11] & 1997 & FFQ & 176 & $15 \pm 11.4$ & 33.0 & 176 & $12.9 \pm 11.8$ & 40.3 \\
\hline PT & EpiPorto [11] & $1999-2003$ & FFQ & 246 & $3.4 \pm 1.6$ & 100.0 & 339 & $3.3 \pm 1.5$ & 100.0 \\
\hline SE & Riksmaten 1997-1998 [39] & $1997-1998$ & $7 \mathrm{dDR}$ & 64 & $7.1 \pm 2.6$ & 86.8 & 58 & $6.1 \pm 2.0$ & 97.4 \\
\hline
\end{tabular}

EAR = Estimated average requirement; DE = Germany; DK = Denmark; ES = Spain; FI = Finland; IR = Ireland; IT = Italy; NE = The Netherlands; $\mathrm{NO}=$ Norway; $\mathrm{PT}=$ Portugal; $\mathrm{SE}=$ Sweden; $\mathrm{UK}=$ United Kingdom; $\mathrm{DH}=$ diet history; $\mathrm{dDR}=$ days dietary record; adj = adjusted for intraindividual variability; $\mathrm{HR}=$ hour recall; $\mathrm{FFQ}$ = food frequency questionnaire.

Tables 1-8 show the intake and prevalence of inadequate intakes for vitamin $\mathrm{C}$, vitamin $\mathrm{D}$, vitamin $\mathrm{B}_{12}$, folic acid, calcium, iron, zinc, selenium, iodine, and copper.

In the adult population, the prevalence of inadequate micronutrient intakes was higher in females than in males for all of the micronutrients except vitamin C. The prevalence of vitamin C inadequacy ranged from 10 to $20 \%$ in most of the nutritional surveys except for the study from Spain that had the lowest prevalence rates (table 1). A prevalence of inadequacy of $21-30 \%$ of the population was found in the nutritional surveys from Belgium (except females), Denmark (only males), Greece (adult population only), Sweden (female adults), and Finland (female elderly). The nutritional surveys from Finland (males only), the UK (except elderly males, with a prevalence above $40 \%$ of the population), Ireland (adult population), and Sweden (male adults) showed that $31-40 \%$ of the target population had usual vitamin $\mathrm{C}$ intakes below the EAR.

The prevalence of vitamin $\mathrm{D}$ inadequacy was above $40 \%$ of the population in all the surveys included in the analysis (table 2).

Prevalence of Inadequate Nutrient Intakes in Europe
For vitamin $\mathrm{B}_{12}$ (table 3), the studies including subjects from Denmark (except female adults), Germany, Portugal, Spain, Sweden (male adults), and the UK (female adults) had a prevalence of inadequacy equal to or below $10 \%$. Adult males from the nutritional surveys from Finland and adult females participating in the surveys from Ireland had a prevalence of inadequacy between 21 and $30 \%$ below the EAR, together with elderly females from the UK and Finland.

All (except adult Italian males) nutritional surveys showed an inadequate intake prevalence for folic acid above $15 \%$ of the population (table 4 ). The prevalence of inadequacy was between 21 and 30\% in subjects comprising the nutritional surveys from Spain and Germany (except female adults in both surveys), Portugal, Finland (only male adults), and the UK (female adults). The adult females from Sweden, Greece, and The Netherlands and the elderly females participating in the surveys from Finland and the UK had a prevalence of inadequacy above $41 \%$.

Regarding the prevalence of calcium inadequacy, the percentage of individuals whose intake was below the 
Table 3. Vitamin $B_{12}(\mu \mathrm{g} /$ day) intake and prevalence of inadequate intake (\% population below EAR) in Europe by gender and population group

\begin{tabular}{|c|c|c|c|c|c|c|c|c|c|}
\hline \multirow{2}{*}{$\begin{array}{l}\text { Coun- } \\
\text { try }\end{array}$} & \multirow{2}{*}{ Study } & \multirow[t]{2}{*}{ Study year } & \multirow{2}{*}{$\begin{array}{l}\text { Food intake } \\
\text { method }\end{array}$} & \multicolumn{3}{|c|}{ Males $(\mathrm{EAR}=1.4 \mu \mathrm{g} /$ day $)$} & \multicolumn{3}{|c|}{ Females $(\mathrm{EAR}=1.4 \mu \mathrm{g} /$ day $)$} \\
\hline & & & & $\mathrm{n}$ & mean $\pm \mathrm{SD}$ & $\begin{array}{l}\text { \% below } \\
\text { EAR }\end{array}$ & $\mathrm{n}$ & mean $\pm \mathrm{SD}$ & $\begin{array}{l}\% \text { below } \\
\text { EAR }\end{array}$ \\
\hline \multicolumn{10}{|c|}{ Adults (age 19-64 years) } \\
\hline $\mathrm{DE}$ & German National Nutrition Survey II [31-33] & 2005-2007 & $\mathrm{DH}$ & 4,912 & $6.6 \pm 3.7$ & 8.0 & 6,016 & $4.4 \pm 2.1$ & 7.7 \\
\hline DK & Danish National Survey of Dietary Habits and PA [28] & $2000-2002$ & $7 \mathrm{dDR}$ & 1,283 & $5.8 \pm 3.3$ & 9.1 & 1,486 & $4.3 \pm 2.6$ & 13.2 \\
\hline ES & ENCAT 2002-2003 [36-38] & 2002-2003 & adj $2 \times 24 \mathrm{HR}$ & 706 & $5.0 \pm 1.0$ & 0.0 & 875 & $4.0 \pm 0.8$ & 0.1 \\
\hline FI & National FINDIET 2007 Survey $[29,30]$ & 2007 & adj $48 \mathrm{HR}$ & 730 & $6.6 \pm 6.5$ & 21.2 & 846 & $4.5 \pm 3.4$ & 18.1 \\
\hline GR & EPIC study [11] & 1994-1999 & FFQ & 500 & $5.3 \pm 11.4$ & 36.6 & 451 & $3.8 \pm 9.7$ & 40.2 \\
\hline IR & SLAN 2007 [34] & 2007 & FFQ & 662 & $5.4 \pm 3.7$ & 14.0 & 717 & $4.1 \pm 3.6$ & 22.7 \\
\hline PT & EPIPORTO [11] & 1999-2003 & FFQ & 917 & $9.3 \pm 4.1$ & 2.7 & 1,472 & $8.8 \pm 4.0$ & 3.2 \\
\hline SE & Riksmaten 1997-1998 [39] & 1997-1998 & $7 \mathrm{dDR}$ & 517 & $6.8 \pm 3.8$ & 7.8 & 575 & $5.9 \pm 5.4$ & 20.2 \\
\hline UK & Health Survey for England [42] & 2000-2001 & $7 \mathrm{dDR}$ & 219 & $6.2 \pm 4.3$ & 13.2 & 259 & $6.1 \pm 3.7$ & 10.2 \\
\hline \multicolumn{10}{|c|}{ Elderly (age $>64$ years) } \\
\hline $\mathrm{DE}$ & German National Nutrition Survey II [31-33] & 2005-2007 & $\mathrm{DH}$ & 1,469 & $5.9 \pm 2.5$ & 3.6 & 1,562 & $4.3 \pm 2.0$ & 7.4 \\
\hline DK & Danish National Survey of Dietary Habits and PA [28] & $2000-2002$ & $7 \mathrm{dDR}$ & 165 & $6.0 \pm 3.3$ & 8.2 & 164 & $4.8 \pm 2.7$ & 10.4 \\
\hline ES & ENCAT 2002-2003 [36-38] & 2002-2003 & adj $2 \times 24 \mathrm{HR}$ & 163 & $3.8 \pm 0.6$ & 0.0 & 179 & $3.5 \pm 0.5$ & 0.0 \\
\hline FI & National FINDIET 2007 Survey $[29,30]$ & 2007 & adj $48 \mathrm{HR}$ & 229 & $6.5 \pm 6.0$ & 19.8 & 234 & $5.2 \pm 4.8$ & 21.4 \\
\hline PT & EpiPorto [11] & 1999-2003 & FFQ & 246 & $8.2 \pm 3.8$ & 3.7 & 339 & $7.5 \pm 4.1$ & 6.8 \\
\hline SE & Riksmaten 1997-1998 [39] & 1997-1998 & $7 \mathrm{dDR}$ & 64 & $8.0 \pm 3.9$ & 4.5 & 58 & $7.4 \pm 4.1$ & 7.2 \\
\hline
\end{tabular}

$\mathrm{EAR}=$ Estimated average requirement; $\mathrm{DE}=$ Germany; DK = Denmark; ES = Spain; FI = Finland $\mathrm{GR}=$ Greece $\mathrm{IR}=\mathrm{Ireland} ; \mathrm{PT}=\mathrm{Portugal} ;$ $\mathrm{SE}=$ Sweden; $\mathrm{UK}=$ United Kingdom; $\mathrm{DH}=$ diet history; $\mathrm{dDR}=$ days dietary record; adj $=$ adjusted for intraindividual variability; HR = hour recall; $\mathrm{FFQ}=$ food frequency questionnaire.

EAR defined by the IOM was above $20 \%$ of the population in most of the nutritional surveys analyzed (table 5)

Regarding the prevalence of iron intake inadequacy (table 6), the prevalence was at or below $10 \%$ of the population in most of the nutritional surveys. Elderly individuals from Denmark, Finland, Norway, Ireland, and Belgium (only females) and adult males from Finland, the UK, and Greece had a prevalence of inadequacy between 11 and $21 \%$.

The prevalence of zinc inadequacy (table 7) was equal to or below $10 \%$ in all of the nutritional surveys included in the analysis except for those from Ireland, the UK, Spain (male elderly), and Germany (female elderly).

Adults from Finland and male adults from The Netherlands had a prevalence of selenium inadequacy equal to or below $10 \%$ of the population (table 8). The prevalence of inadequacy was at or above $30 \%$ in the nutritional surveys from Denmark, Sweden, and Italy (elderly females only).

Regarding iodine, only four countries had suitable data (table 8). The studies from Denmark (adults and elderly males) and Finland (only elderly) had $10 \%$ or less of the population with inadequate intakes. More than $20 \%$ of the adult population from Finland, the adult and elderly population from Germany, and the elderly from Ireland (female only) had iodine intakes below the EAR.
For copper (table 8), the prevalence of inadequacy was at or below 10\% in Finnish males and male adults from Italy. The prevalence was above $20 \%$ in the nutritional surveys from Ireland (adult females and elderly males) and female adults from the UK.

The micronutrients that were included as study variables for the majority of countries were: vitamin C, vitamin $D$, vitamin $B_{12}$, folic acid, calcium, iron (males only), and zinc. The countries that had this information were Germany, Denmark, Spain, Finland, Ireland, Sweden, and the UK. Figure 1 shows the countries according to the number of nutrients whose intake was found to be inadequate (above $20 \%$ of the population) for both males and females. Finland and Sweden had the highest ratios of inadequate intakes among males and Ireland and the UK among females.

\section{Discussion}

The analysis of nutrient intake data in Europe showed a mean prevalence of inadequacy at or below $10 \%$ of the population for zinc, iron, and vitamin $\mathrm{B}_{12}$ (only in the elderly population); the prevalence was between 11 and $20 \%$ for copper in the adult and elderly populations, for 
Table 4. Folic acid ( $\mu \mathrm{g} /$ day) intake and prevalence of inadequate intake (\% population below EAR) in Europe by gender and population group

\begin{tabular}{|c|c|c|c|c|c|c|c|c|c|}
\hline \multirow{2}{*}{$\begin{array}{l}\text { Coun- } \\
\text { try }\end{array}$} & \multirow{2}{*}{ Study } & \multirow[t]{2}{*}{ Study year } & \multirow{2}{*}{$\begin{array}{l}\text { Food intake } \\
\text { method }\end{array}$} & \multicolumn{3}{|c|}{ Males $(\mathrm{EAR}=200 \mu \mathrm{g} / \mathrm{day})$} & \multicolumn{3}{|c|}{ Females $(\mathrm{EAR}=200 \mu \mathrm{g} /$ day $)$} \\
\hline & & & & $\mathrm{n}$ & mean $\pm S D$ & $\begin{array}{l}\text { \% below } \\
\text { EAR }\end{array}$ & $\mathrm{n}$ & mean $\pm S D$ & $\begin{array}{l}\text { \% below } \\
\text { EAR }\end{array}$ \\
\hline \multicolumn{10}{|c|}{ Adults (age 19-64 years) } \\
\hline $\mathrm{DE}$ & German National Nutrition Survey II [31-33] & 2005-2007 & DH & 4,912 & $321 \pm 202$ & 27.5 & 6,016 & $277 \pm 124$ & 26.7 \\
\hline DK & Danish National Survey of Dietary Habits and PA [28] & 1997 & $7 \mathrm{dDR}$ & 1,283 & $323 \pm 120$ & 15.3 & 1,486 & $296 \pm 111$ & 19.4 \\
\hline ES & ENCAT 2002-2003 [36-38] & $2002-2003$ & adj $2 \times 24 \mathrm{HR}$ & 706 & $237 \pm 45$ & 20.5 & 875 & $220 \pm 48$ & 33.8 \\
\hline FI & National FINDIET 2007 Survey $[29,30]$ & 2007 & adj $48 \mathrm{HR}$ & 730 & $270 \pm 120$ & 28.0 & 846 & $226 \pm 88$ & 38.4 \\
\hline GR & EPIC study $[11]$ & 1994-1999 & FFQ & 500 & $283 \pm 190$ & 33.1 & 451 & $221 \pm 184$ & 45.5 \\
\hline IR & SLAN 2007 [34] & 2007 & FFQ & 662 & $332 \pm 128$ & 15.1 & 717 & $260 \pm 144$ & 33.8 \\
\hline IT & INN-CA Study [35] & 1994-1996 & $7 \mathrm{dDR}$ & 660 & $315 \pm 91$ & 10.3 & 801 & $283 \pm 100$ & 20.3 \\
\hline NE & Dutch National Food Consumption Survey $2003[40,41]$ & 2003 & $2 \times 24 \mathrm{HR}$ & 352 & $219 \pm 73$ & 39.8 & 398 & $146 \pm 40$ & 91.0 \\
\hline PT & EpiPorto [11] & 1999-2003 & FFQ & 917 & $302 \pm 130$ & 21.6 & 1,472 & $304 \pm 144$ & 23.5 \\
\hline SE & Riksmaten 1997-1998 [39] & $1997-1998$ & $7 \mathrm{dDR}$ & 517 & $232 \pm 73$ & 33.1 & 575 & $215 \pm 65$ & 40.9 \\
\hline UK & Health Survey for England [42] & $2000-2001$ & $7 \mathrm{dDR}$ & 219 & $376 \pm 224$ & 18.2 & 210 & $249 \pm 113$ & 25.8 \\
\hline \multicolumn{10}{|c|}{ Elderly (age $>64$ years) } \\
\hline $\mathrm{DE}$ & German National Nutrition Survey II [31-33] & 2005-2007 & DH & 1,469 & $276 \pm 93$ & 20.7 & 1,562 & $276 \pm 93$ & 20.7 \\
\hline DK & Danish National Survey of Dietary Habits and PA [28] & $2000-2002$ & $7 \mathrm{dDR}$ & 165 & $308 \pm 122$ & 18.8 & 164 & $297 \pm 112$ & 19.3 \\
\hline ES & ENCAT 2002-2003 [36-38] & $2002-2003$ & adj $2 \times 24 \mathrm{HR}$ & 163 & $236 \pm 47$ & 22.2 & 179 & $216 \pm 28$ & 28.4 \\
\hline FI & National FINDIET 2007 Survey $[29,30]$ & 2007 & adj $48 \mathrm{HR}$ & 229 & $243 \pm 102$ & 33.7 & 234 & $210 \pm 96$ & 45.9 \\
\hline IR & SLAN 2007 [34] & 2007 & FFQ & 580 & $343 \pm 148$ & 16.7 & 742 & $335 \pm 145$ & 17.6 \\
\hline IT & INN-CA Study [35] & 1994-1996 & $7 \mathrm{dDR}$ & n.a. & n.a. & n.a. & 107 & $279 \pm 174$ & 32.5 \\
\hline PT & EpiPorto [11] & 1999-2003 & FFQ & 246 & $312 \pm 156$ & 23.6 & 339 & $290 \pm 163$ & 29.0 \\
\hline SE & Riksmaten 1997-1998 [39] & 1997-1998 & $7 \mathrm{dDR}$ & 64 & $240 \pm 75$ & 29.7 & 58 & $237 \pm 81$ & 32.4 \\
\hline
\end{tabular}

EAR = Estimated average requirement; DE = Germany; DK = Denmark; ES = Spain; FI = Finland; GR = Greece; IR = Ireland; IT = Italy; NE = The Netherlands; $\mathrm{PT}=$ Portugal; $\mathrm{SE}=$ Sweden; $\mathrm{UK}=$ United Kingdom; $\mathrm{DH}=$ diet history; $\mathrm{dDR}=$ days dietary record; adj = adjusted for intraindividual variability; $\mathrm{HR}$ = hour recall; FFQ = food frequency questionnaire; n.a. = not available.

vitamin $B_{12}$ in the adult population, and for vitamin $C$ in elderly Europeans. The micronutrients with a prevalence of inadequacy above $21 \%$ of the population were vitamin $\mathrm{D}$, folic acid, calcium selenium, and iodine in the adults and elderly and vitamin $\mathrm{C}$ in the adults only.

When calculating nutrient intake adequacy, a decision must be made regarding the threshold to define an acceptable level of inadequacy for every nutrient under study. The World Health Organization (WHO) set a $2-3 \%$ level as the maximum desirable prevalence of inadequate intake when planning food supplementation [49]. The governmental institution Health Canada determined the level of less than $10 \%$ as the threshold to develop Canada's Food Guide [50]. In the present analysis, a more lenient threshold would be more appropriate because several methodological aspects affected the calculation of the number of individuals whose intake was below the EAR $[14,21]$. In the first place, we used published data and had no access to raw data. Secondly, individuals underreporting their intake were not excluded from the analysis. Lastly, supplement intake or food fortification

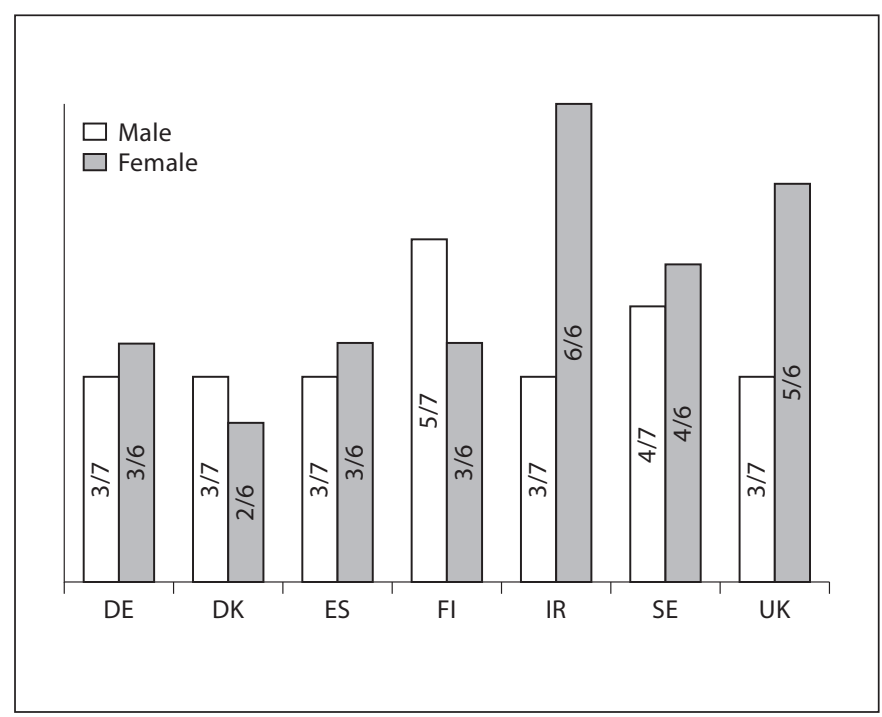

Fig. 1. Countries with data for 7 vitamins and minerals (6 for females) classified according to the number of nutrients with inadequate intakes above $20 \%$ of the population. DE = Germany; $\mathrm{DK}=$ Denmark; ES = Spain; FI = Finland; IR = Ireland; SE = Sweden; UK = United Kingdom. 
Table 5. Calcium intake (mg/day) and prevalence of inadequate intake (\% population below EAR) in Europe by gender and population group

\begin{tabular}{|c|c|c|c|c|c|c|c|c|c|}
\hline \multirow{2}{*}{\multicolumn{2}{|c|}{$\begin{array}{l}\text { Coun- Study } \\
\text { try }\end{array}$}} & \multirow[t]{2}{*}{ Study year } & \multirow{2}{*}{$\begin{array}{l}\text { Food intake } \\
\text { method }\end{array}$} & \multicolumn{3}{|l|}{ Males } & \multicolumn{3}{|c|}{ Females } \\
\hline & & & & $\mathrm{n}$ & mean $\pm \mathrm{SD}$ & $\begin{array}{l}\text { \% below } \\
\text { EAR }\end{array}$ & $\mathrm{n}$ & mean \pm SD & $\begin{array}{l}\text { \% below } \\
\text { EAR }\end{array}$ \\
\hline \multicolumn{4}{|c|}{ Adults (age 19-64 years) } & \multicolumn{3}{|c|}{$\mathrm{EAR}=800 \mathrm{mg} /$ day } & \multicolumn{3}{|c|}{$\mathrm{EAR}=800 \mathrm{mg} /$ day } \\
\hline $\mathrm{BE}$ & Belgian Food Consumption Survey [27] & 2004 & adj $2 \times 24 \mathrm{HR}$ & n.a. & $847 \pm 326$ & 44.3 & n.a. & $750 \pm 260$ & 57.6 \\
\hline $\mathrm{DE}$ & German National Nutrition Survey II [31-33] & 2005-2007 & $\mathrm{DH}$ & 4,912 & $1,171 \pm 556$ & 25.2 & 6,016 & $1,047 \pm 389$ & 26.3 \\
\hline DK & Danish National Survey of Dietary Habits and PA [28] & $2000-2002$ & $7 \mathrm{dDR}$ & 1,283 & $1,055 \pm 448$ & 28.5 & 1,486 & $990 \pm 389$ & 31.3 \\
\hline ES & ENCAT 2002-2003 [36-38] & $2002-2003$ & adj $2 \times 24 \mathrm{HR}$ & 706 & $830 \pm 200$ & 44.0 & 875 & $778 \pm 170$ & 55.1 \\
\hline FI & National FINDIET 2007 Survey $[29,30]$ & 2007 & adj $48 \mathrm{HR}$ & 730 & $1,202 \pm 592$ & 24.9 & 846 & $1,007 \pm 450$ & 32.3 \\
\hline FR & National Nutrition and Health Survey [11] & 2006-2007 & $3 \times 24 \mathrm{HR}$ & 852 & $981 \pm 16$ & 0.0 & 1,499 & $841 \pm 13$ & 0.1 \\
\hline GR & EPIC study [11] & 1994-1999 & FFQ & 500 & $991 \pm 614$ & 37.8 & 451 & $744 \pm 438$ & 55.1 \\
\hline IR & SLAN 2007 [34] & 2007 & FFQ & 662 & $949 \pm 354$ & 33.7 & 717 & $742 \pm 299$ & 57.7 \\
\hline IT & INN-CA Study [35] & $1994-1996$ & $7 \mathrm{dDR}$ & 660 & $947 \pm 309$ & 31.7 & 801 & $851 \pm 264$ & 42.3 \\
\hline NE & Dutch National Food Consumption Survey $[40,41]$ & 2003 & adj $2 \times 24 \mathrm{HR}$ & 352 & $1,101 \pm 362$ & 20.3 & 398 & $919 \pm 356$ & 36.9 \\
\hline NO & Norkost 1997 [11] & 1997 & FFQ & 1,050 & $1,068 \pm 460$ & 28.0 & 1,146 & $833 \pm 340$ & 46.1 \\
\hline PT & EpiPorto [11] & 1999-2003 & FFQ & 917 & $883 \pm 354$ & 40.7 & 1,472 & $963 \pm 395$ & 34.0 \\
\hline SE & Riksmaten 1997-1998 [39] & $1997-1998$ & $7 \mathrm{dDR}$ & 517 & $1,069 \pm 395$ & 24.8 & 575 & $922 \pm 300$ & 34.2 \\
\hline UK & Health Survey for England [42] & $2000-2001$ & $7 \mathrm{dDR}$ & 219 & $1,030 \pm 606$ & 35.2 & 210 & $736 \pm 233$ & 60.8 \\
\hline \multicolumn{4}{|c|}{ Elderly (age $>64$ years) } & \multicolumn{3}{|c|}{$\mathrm{EAR}=1,000 \mathrm{mg} /$ day } & \multicolumn{3}{|c|}{$\mathrm{EAR}=1,000 \mathrm{mg} /$ day } \\
\hline $\mathrm{BE}$ & Belgian Food Consumption Survey [27] & 2004 & adj $2 \times 24 \mathrm{HR}$ & n.a. & $698 \pm 281$ & 85.9 & n.a. & $615 \pm 225$ & 95.6 \\
\hline $\mathrm{DE}$ & German National Nutrition Survey II [31-33] & 2005-2007 & DH & 1,469 & $970 \pm 357$ & 53.3 & 1,562 & $918 \pm 342$ & 59.5 \\
\hline DK & Danish National Survey of Dietary Habits and PA [28] & $2000-2002$ & $7 \mathrm{dDR}$ & 165 & $874 \pm 359$ & 63.7 & 164 & $900 \pm 366$ & 60.8 \\
\hline ES & ENCAT 2002-2003 [36-38] & $2002-2003$ & adj $2 \times 24 \mathrm{HR}$ & 163 & $757 \pm 152$ & 94.5 & 179 & $712 \pm 108$ & 99.6 \\
\hline FI & National FINDIET 2007 Survey $[29,30]$ & 2007 & adj $48 \mathrm{HR}$ & 229 & $1,032 \pm 521$ & 47.6 & 234 & $900 \pm 426$ & 59.3 \\
\hline FR & National Nutrition and Health Survey [11] & $2006-2007$ & $3 \times 24 \mathrm{HR}$ & 130 & $893 \pm 28$ & 100.0 & 219 & $818 \pm 22$ & 100.0 \\
\hline IR & SLAN 2007 [34] & 2007 & FFQ & 580 & $892 \pm 403$ & 60.6 & 742 & $823 \pm 370$ & 68.4 \\
\hline NO & Norkost 1997 [11] & 1997 & FFQ & 176 & $861 \pm 349$ & 65.5 & 176 & $776 \pm 266$ & 80.0 \\
\hline PT & EpiPorto [11] & 1999-2003 & FFQ & 246 & $853 \pm 316$ & 67.9 & 339 & $904 \pm 375$ & 60.1 \\
\hline
\end{tabular}

$\mathrm{EAR}=$ Estimated average requirement; $\mathrm{BE}=$ Belgium; $\mathrm{DE}=$ Germany; $\mathrm{DK}=$ Denmark; $\mathrm{ES}=$ Spain $; \mathrm{FI}=$ Finland $; \mathrm{FR}=\mathrm{France} ; \mathrm{GR}=\mathrm{Greece} ; \mathrm{IR}=$ Ireland; IT = Italy; $\mathrm{NE}=$ The Netherlands; $\mathrm{NO}=$ Norway; $\mathrm{PT}=$ Portugal; $\mathrm{SE}=$ Sweden; $\mathrm{UK}=$ United Kingdom; adj = adjusted for intraindividual variability; $\mathrm{DH}$ = diet history; $\mathrm{dDR}$ = days dietary record; $\mathrm{HR}$ = hour recall; $\mathrm{FFQ}=$ food frequency questionnaire; . a. = not available.

was not taken into account (only in the nutritional surveys from Ireland and Norway). The exclusion of underreporters and the inclusion of supplement intake and food fortification as part of the total intake would have reduced the prevalence of nutrient intake inadequacy [13]. A review by Poslusna et al. [51] evaluating the effect of misreporting on energy and nutrient intake estimation indicated that low energy reporters had lower mean intakes for several micronutrients (ranging from 25 to 36\%) compared to nonunderreporters. Regarding supplement intake, the prevalence of consumption varies enormously across European countries, with a clear north-south gradient [52]. In the Nordic countries, more than $40 \%$ of the population is a usual consumer, whereas in Southern Europe the prevalence is quite low (5\%). In countries with higher levels of consumption, dietary supplement intake might have contributed to improving the adequacy of diets [53-55]. In addition, we assumed that the nutrients of interest followed a symmetrical distribution as a condition to apply the EAR cut point, which may be too liberal an assumption given the high coefficient of variation found for certain nutrients, ranging from $30 \%$ for the studies evaluating zinc intake in the elderly population group to $79 \%$ for the intake of vitamin $B_{12}$ in the adult population group (data not shown) [13,49]. In the case of a skewed distribution for a given nutrient intake in any of the nutritional surveys analyzed, the true prevalence of inadequacy would be underestimated [14]. Another issue concerns data on vitamin D intakes. In the Nordic countries, vitamin $\mathrm{D}$ fortification of the food supply is mandatory.

The nutrients at risk in non-European developed countries are similar to those found in this analysis. In the USA, data from the NHANES III revealed that, among the adult and elderly, around $20 \%$ of females and $7 \%$ of males had folic acid intakes below the EAR [56]. Data from the 
Table 6. Iron intake (mg/day) and prevalence of inadequate intake (\% population below EAR) in Europe by gender and population group

\begin{tabular}{|c|c|c|c|c|c|c|c|c|c|}
\hline \multirow{2}{*}{\multicolumn{2}{|c|}{$\begin{array}{l}\text { Coun- Study } \\
\text { try }\end{array}$}} & \multirow[t]{2}{*}{ Study year } & \multirow{2}{*}{$\begin{array}{l}\text { Food intake } \\
\text { method }\end{array}$} & \multicolumn{3}{|c|}{ Males (EAR = 7 mg/day) } & \multicolumn{3}{|c|}{ Females $(\mathrm{EAR}=6 \mathrm{mg} /$ day $)$} \\
\hline & & & & $\mathrm{n}$ & mean $\pm \mathrm{SD}$ & $\begin{array}{l}\text { \% below } \\
\text { EAR }\end{array}$ & $\mathrm{n}$ & mean $\pm \mathrm{SD}$ & $\begin{array}{l}\% \text { below } \\
\text { EAR }\end{array}$ \\
\hline \multicolumn{10}{|c|}{ Adults (age 19-64 years) } \\
\hline $\mathrm{BE}$ & Belgian Food Consumption Survey [27] & 2004 & $\operatorname{adj} 2 \times 24 \mathrm{HR}$ & n.a. & $13.3 \pm 3.1$ & 2.1 & & & \\
\hline $\mathrm{DE}$ & German National Nutrition Survey II [31-33] & 2005-2007 & $\mathrm{DH}$ & 4,912 & $15.5 \pm 5.8$ & 7.1 & & & \\
\hline DK & Danish National Survey of Dietary Habits and PA [28] & $2000-2002$ & $7 \mathrm{dDR}$ & 1,283 & $11.1 \pm 3.3$ & 10.7 & & & \\
\hline ES & ENCAT 2002-2003 [36-38] & $2002-2003$ & $\operatorname{adj} 2 \times 24 \mathrm{HR}$ & 706 & $13 \pm 1.8$ & 0.0 & & & \\
\hline FI & National FINDIET 2007 Survey $[29,30]$ & 2007 & adj $48 \mathrm{HR}$ & 730 & $13.6 \pm 5.7$ & 12.3 & & & \\
\hline GR & EPIC study $[11]$ & 1994-1999 & FFQ & 500 & $13.7 \pm 6.4$ & 14.8 & & & \\
\hline IR & SLAN 2007 [34] & 2007 & FFQ & 662 & $14.4 \pm 5.5$ & 8.9 & & & \\
\hline IT & INN-CA Study [35] & 1994-1996 & $7 \mathrm{dDR}$ & 660 & $14.7 \pm 3.9$ & 2.4 & & & \\
\hline NE & Dutch National Food Consumption Survey $[40,41]$ & 2003 & $\operatorname{adj} 2 \times 24 \mathrm{HR}$ & 352 & $12.2 \pm 2.3$ & 1.2 & & & \\
\hline NO & Norkost $1997[11]$ & 1997 & FFQ & 1,050 & $13.4 \pm 5.1$ & 10.5 & & & \\
\hline PT & EpiPorto [11] & 1999-2003 & FFQ & 917 & $16.7 \pm 4.6$ & 1.7 & & & \\
\hline SE & Riksmaten 1997-1998 [39] & 1997-1998 & $7 \mathrm{dDR}$ & 517 & $12.4 \pm 3.4$ & 5.6 & & & \\
\hline UK & Health Survey for England [42] & $2000-2001$ & $7 \mathrm{dDR}$ & 219 & $13.9 \pm 7.5$ & 17.9 & & & \\
\hline \multicolumn{10}{|c|}{ Elderly (age $>64$ years) } \\
\hline $\mathrm{BE}$ & Belgian Food Consumption Survey [27] & 2004 & adj $2 \times 24 \mathrm{HR}$ & n.a. & $11.6 \pm 2.8$ & 5.0 & n.a. & $8.7 \pm 2.6$ & 15.0 \\
\hline $\mathrm{DE}$ & German National Nutrition Survey II [31-33] & 2005-2007 & $\mathrm{DH}$ & 1,469 & $13.6 \pm 3.9$ & 4.5 & 1,562 & $11.4 \pm 3.5$ & 6.1 \\
\hline DK & Danish National Survey of Dietary Habits and PA [28] & $2000-2002$ & $7 \mathrm{dDR}$ & 165 & $10.7 \pm 3.7$ & 15.9 & 164 & $8.5 \pm 2.2$ & 12.8 \\
\hline ES & ENCAT 2002-2003 [36-38] & $2002-2003$ & adj $2 \times 24 \mathrm{HR}$ & 163 & $11.2 \pm 1.3$ & 0.1 & 179 & $9.6 \pm 1.0$ & 0.0 \\
\hline FI & National FINDIET 2007 Survey $[29,30]$ & 2007 & adj $48 \mathrm{HR}$ & 229 & $12.6 \pm 5.6$ & 15.9 & 234 & $9.9 \pm 3.6$ & 13.9 \\
\hline IR & SLAN 2007 [34] & 2007 & FFQ & 580 & $12.6 \pm 6.8$ & 20.5 & 742 & $12.1 \pm 6.3$ & 16.6 \\
\hline IT & INN-CA Study [35] & 1994-1996 & $7 \mathrm{dDR}$ & n.a. & n.a. & n.a. & 107 & $11.5 \pm 3.1$ & 3.8 \\
\hline NO & Norkost 1997 [11] & 1997 & FFQ & 176 & $12.3 \pm 5.6$ & 17.2 & 176 & $10.8 \pm 4.6$ & 14.8 \\
\hline PT & EpiPorto [11] & 1999-2003 & FFQ & 246 & $16.3 \pm 4.8$ & 2.6 & 339 & $14.2 \pm 4.7$ & 4.1 \\
\hline
\end{tabular}

$\mathrm{EAR}=$ Estimated average requirement; $\mathrm{BE}=$ Belgium; $\mathrm{DE}=$ Germany; $\mathrm{DK}=$ Denmark $\mathrm{ES}=$ Spain; FI $=$ Finland; $\mathrm{GR}=\mathrm{Greece} ; \mathrm{IR}=\mathrm{Ireland} ; \mathrm{IT}=$ Italy; NE = The Netherlands; NO = Norway; PT = Portugal; $\mathrm{SE}=$ Sweden; UK = United Kingdom; adj = adjusted for intraindividual variability; $\mathrm{DH}=$ diet history; $\mathrm{dDR}=$ days dietary record; $\mathrm{HR}=$ hour recall; $\mathrm{FFQ}=$ food frequency questionnaire; .. . = not available.

NHANES 2001-2002 indicated that 31\% of the population consumed vitamin $\mathrm{C}$ in amounts below the EAR, and $12 \%$ had zinc intakes and $8 \%$ had folic acid intakes below the EAR [57]. In Canada, the Canadian Community Health Survey conducted in 2004 showed that, among adult Canadians, $10-35 \%$ of the population had vitamin $\mathrm{B}_{12}$ and vitamin C intakes below the EAR. Similarly, $10-35 \%$ of Canadians from most age and sex groups consumed folic acid, vitamin B6, and zinc in inadequate amounts [58].

Although a cross-country comparison of nutritional surveys conducted following different methodologies represents a great challenge, such an analysis can offer interesting results. Ideally, in nutritional data on all European countries derived from studies using the same methodology, the main difference in nutrient intake would basically be from the variation in food availability for the countries analyzed. In the present analysis, the fact that data were derived from studies conducted with different methodologies, as well as the distinct dietary intake methods used, seemed to impact on some of the results obtained. For certain nutrients (vitamin $\mathrm{C}$ and iron), countries using a register or diary as the dietary intake instrument had mean nutrient intake values lower than those of countries using an FFQ. The intake variability was also higher in those nutritional surveys using a FFQ (for vitamin C, folic acid, and iron) as the method to estimate the dietary intake, which can be attributed to random measurement error [18]. When conducting nutritional surveys, the main purpose of the study will determine the study design and thus the dietary intake method to be used. If the purpose of the nutritional survey is to estimate the prevalence of nutrient intake inadequacy, the validation study should address questions such as the sensitivity and specificity of the questionnaire [59]. To overcome any possible measurement error in the estimation of the usual intake, we included only those 
Table 7. Zinc intake (mg/day) and prevalence of inadequate intake (\% population below EAR) in Europe by gender and population group

\begin{tabular}{|c|c|c|c|c|c|c|c|c|c|}
\hline \multirow{2}{*}{$\begin{array}{l}\text { Coun- } \\
\text { try }\end{array}$} & \multirow{2}{*}{ Study } & \multirow[t]{2}{*}{ Study year } & \multirow{2}{*}{$\begin{array}{l}\text { Food intake } \\
\text { method }\end{array}$} & \multicolumn{3}{|c|}{ Males $(\mathrm{EAR}=6.4 \mathrm{mg} /$ day $)$} & \multicolumn{3}{|c|}{ Females $(\mathrm{EAR}=5.7 \mathrm{mg} /$ day $)$} \\
\hline & & & & $\mathrm{n}$ & mean $\pm \mathrm{SD}$ & $\begin{array}{l}\text { \% below } \\
\text { EAR }\end{array}$ & $\mathrm{n}$ & mean $\pm S D$ & $\begin{array}{l}\% \text { below } \\
\text { EAR }\end{array}$ \\
\hline \multicolumn{10}{|c|}{ Adults (age 19-64 years) } \\
\hline $\mathrm{DE}$ & German National Nutrition Survey II [31-33] & 2005-2007 & $\mathrm{DH}$ & 4,912 & $12.6 \pm 4.9$ & 10.3 & 6,016 & $9.7 \pm 3.1$ & 9.8 \\
\hline DK & Danish National Survey of Dietary Habits and PA [28] & 2000-2002 & $7 \mathrm{dDR}$ & 1,283 & $12.3 \pm 3.6$ & 5.1 & 1,486 & $9.7 \pm 2.6$ & 6.2 \\
\hline ES & ENCAT 2002-2003 [36-38] & $2002-2003$ & adj $2 \times 24 \mathrm{HR}$ & 706 & $9.4 \pm 1.4$ & 1.6 & 875 & $7.8 \pm 1.2$ & 4.0 \\
\hline FI & National FINDIET 2007 Survey $[29,30]$ & 2007 & adj $48 \mathrm{HR}$ & 730 & $13.6 \pm 4.8$ & 6.7 & 846 & $10.0 \pm 3.3$ & 9.6 \\
\hline IR & SLAN 2007 [34] & 2007 & FFQ & 662 & $11.6 \pm 4.4$ & 11.9 & 717 & $8.5 \pm 5.0$ & 28.8 \\
\hline IT & INN-CA Study [35] & $1994-1996$ & $7 \mathrm{dDR}$ & 660 & $12.9 \pm 3.2$ & 2.1 & 801 & $10.7 \pm 2.8$ & 3.7 \\
\hline NE & Dutch National Food Consumption Survey $[40,41]$ & 2003 & adj $2 \times 24 \mathrm{HR}$ & 352 & $11.2 \pm 2.0$ & 0.8 & 398 & $8.3 \pm 2.0$ & 9.7 \\
\hline SE & Riksmaten 1997-1998 [39] & 1997-1998 & $7 \mathrm{dDR}$ & 517 & $12.7 \pm 3.4$ & 3.2 & 575 & $9.9 \pm 2.4$ & 4.0 \\
\hline UK & Health Survey for England [42] & $2000-2001$ & $7 \mathrm{dDR}$ & 219 & $10.7 \pm 4.4$ & 16.4 & 210 & $7.1 \pm 2.9$ & 31.0 \\
\hline \multicolumn{10}{|c|}{ Elderly (age $>64$ years) } \\
\hline $\mathrm{DE}$ & German National Nutrition Survey II [31-33] & 2005-2007 & $\mathrm{DH}$ & 1,469 & $10.9 \pm 3.2$ & 8.0 & 1,562 & $8.8 \pm 2.8$ & 13.4 \\
\hline DK & Danish National Survey of Dietary Habits and PA [28] & $2000-2002$ & $7 \mathrm{dDR}$ & 165 & $11.0 \pm 3.6$ & 10.1 & 164 & $9.1 \pm 2.6$ & 9.5 \\
\hline ES & ENCAT 2002-2003 [36-38] & $2002-2003$ & adj $2 \times 24 \mathrm{HR}$ & 163 & $7.5 \pm 1.0$ & 13.6 & 179 & $6.8 \pm 0.7$ & 5.8 \\
\hline FI & National FINDIET 2007 Survey $[29,30]$ & 2007 & adj $48 \mathrm{HR}$ & 229 & $12.3 \pm 4.3$ & 8.5 & 234 & $9.4 \pm 2.9$ & 10.1 \\
\hline IR & SLAN 2007 [34] & 2007 & FFQ & 580 & $11.9 \pm 5.0$ & 13.6 & 742 & $11.2 \pm 4.9$ & 13.1 \\
\hline IT & INN-CA Study [35] & 1994-1996 & $7 \mathrm{dDR}$ & 60 & $12.2 \pm 3.5$ & 4.9 & 107 & $9.8 \pm 2.5$ & 5.1 \\
\hline
\end{tabular}

$\mathrm{EAR}=$ Estimated average requirement; DE = Germany; DK = Denmark; ES = Spain; FI = Finland; IR = Ireland; IT = Italy; NE = The Netherlands; $\mathrm{SE}=$ Sweden; $\mathrm{UK}=$ United Kingdom; $\mathrm{DH}=$ diet history; $\mathrm{dDR}=$ days dietary record; $\mathrm{HR}=$ hour recall; $\mathrm{FFQ}=$ food frequency questionnaire; adj = adjusted for intraindividual variability.

nutritional surveys using a validated FFQ, although the purpose of the validation study could have been something other than to estimate nutrient intake adequacy. Thus, even having been validated, the FFQ could be a good instrument to estimate dietary intake or to rank individuals but would not be valid for estimating nutrient intake. The number of food items included, the portion size estimation, the food composition table used, etc., are factors related to the validation protocol that can affect the estimation of nutrient intake. For those nutrients found in a limited number of foods, using a method of register or a diary will probably miss information on days of intake registered, whereas an FFQ will overestimate the intake of certain food groups such as vegetables [60]. These misreporting errors will affect the analysis of the prevalence of nutrient intake adequacy when applying the EAR cut point method.

Finally, the method used to estimate nutrient intake adequacy (EAR cut point) is a key determinant of the results shown. Using such a method, the distribution of the nutrient intake in the population under study affects the resulting prevalence of inadequacy almost as much as the level of mean intake. Before the definition of the EAR cut point, the adequacy of nutrient intake in the population was calculated using several methods, such as certain cut points of the individual nutrient level $\left(\operatorname{INL}_{98}\right)(2 / 3,1 / 3$, etc.), diverse indexes, or comparison of the mean intake against the $\mathrm{INL}_{98}$. Several authors have shown how the method used can affect the estimation of nutrient intake inadequacy $[61,62]$. The use of a cut point at $\mathrm{INL}_{98}$ overestimates the true prevalence of inadequate intakes when compared to the EAR cut point method [62]. Due to the between-person variability, comparing the mean intake of the nutrient of interest against the EAR for that nutrient can lead to misinterpretation of the true prevalence of inadequacy [61]. As the EAR cut point method has been adopted as the best method to estimate nutrient intake inadequacy [13], the comparison of nutritional surveys will be clearly affected by the study design and methodology.

\section{Conclusions}

Although cross country comparability is limited by the heterogeneity in study designs, study purposes, and methodologies, the present analysis showed that the following four micronutrients had higher risk of inadequate intakes in Europe: folic acid, selenium, iodine and vitamin C (the latter only in the elderly). 
Table 8. Intake of selenium ( $\mu \mathrm{g} /$ day), iodine ( $\mu \mathrm{g} / \mathrm{day})$, and copper (mg/day) and prevalence of inadequate intake (\% population below EAR) in Europe by gender and population group

\begin{tabular}{|c|c|c|c|c|c|c|c|c|c|}
\hline \multirow{2}{*}{$\begin{array}{l}\text { Coun- } \\
\text { try }\end{array}$} & \multirow[t]{2}{*}{ Study } & \multirow[t]{2}{*}{ Study year } & \multirow{2}{*}{$\begin{array}{l}\text { Food intake } \\
\text { method }\end{array}$} & \multicolumn{3}{|l|}{ Male } & \multicolumn{3}{|c|}{ Female } \\
\hline & & & & $\mathrm{n}$ & $\begin{array}{l}\text { mean } \pm \\
\mathrm{SD}\end{array}$ & $\begin{array}{l}\text { \% below } \\
\text { EAR }\end{array}$ & $\mathrm{n}$ & $\begin{array}{l}\text { mean } \pm \\
\mathrm{SD}\end{array}$ & $\begin{array}{l}\text { \% below } \\
\text { EAR }\end{array}$ \\
\hline \multicolumn{10}{|c|}{ Selenium } \\
\hline \multicolumn{4}{|c|}{ Adults (age 19-64 years) } & \multicolumn{3}{|c|}{$\mathrm{EAR}=35 \mu \mathrm{g} / \mathrm{day}$} & \multicolumn{3}{|c|}{$\mathrm{EAR}=30 \mu \mathrm{g} / \mathrm{day}$} \\
\hline DK & Danish National Survey of Dietary Habits and PA [28] & $2000-2002$ & $7 \mathrm{dDR}$ & 1,283 & $42 \pm 14$ & 30.9 & 1,486 & $34 \pm 11$ & 35.8 \\
\hline FI & National FINDIET 2007 Survey $[29,30]$ & 2007 & adj $48 \mathrm{HR}$ & 730 & $73 \pm 27$ & 8.0 & 846 & $54 \pm 19$ & 10.3 \\
\hline IT & INN-CA Study [35] & 1994-1996 & $7 \mathrm{dDR}$ & 660 & $48 \pm 20$ & 25.8 & 801 & $39 \pm 16$ & 28.7 \\
\hline $\mathrm{NE}$ & Dutch National Food Consumption Survey 2003 [40, 41] & 2003 & adj $2 \times 24 \mathrm{HR}$ & 352 & $51 \pm 11$ & 8.4 & 398 & $38 \pm 6$ & 11.6 \\
\hline SE & Riksmaten 1997-1998 [39] & 1997-1998 & $7 \mathrm{dDR}$ & 517 & $36 \pm 12$ & 46.7 & 575 & $31 \pm 11$ & 46.4 \\
\hline \multicolumn{10}{|c|}{ Elderly (age >64 years) } \\
\hline DK & Danish National Survey of Dietary Habits and PA [28] & 2000-2002 & $7 \mathrm{dDR}$ & 165 & $39 \pm 13$ & 37.9 & 164 & $34 \pm 11$ & 35.8 \\
\hline FI & National FINDIET 2007 Survey $[29,30]$ & 2007 & adj $48 \mathrm{HR}$ & 229 & $66 \pm 26$ & 11.7 & 234 & $49 \pm 17$ & 13.2 \\
\hline IR & SLAN 2007 [34] & 2007 & FFQ & 580 & $62 \pm 27$ & 15.9 & 742 & $55 \pm 24$ & 14.9 \\
\hline IT & INN-CA Study [35] & 1994-1996 & $7 \mathrm{dDR}$ & 60 & $43 \pm 18$ & 32.8 & 107 & $37 \pm 15$ & 32.0 \\
\hline SE & Riksmaten 1997-1998 [39] & $1997-1998$ & $7 \mathrm{dDR}$ & 64 & $40 \pm 14$ & 36.0 & 58 & $37 \pm 14$ & 30.9 \\
\hline \multicolumn{10}{|l|}{ Iodine } \\
\hline \multicolumn{4}{|c|}{ Adults (age 19-64 years) } & \multicolumn{3}{|c|}{$\mathrm{EAR}=100 \mu \mathrm{g} /$ day } & \multicolumn{3}{|c|}{$\mathrm{EAR}=100 \mu \mathrm{g} /$ day } \\
\hline $\mathrm{DE}$ & German National Nutrition Survey II [31-33] & 2005-2007 & DH & 4,912 & $108 \pm 46$ & 43.1 & 6,016 & $101 \pm 40$ & 49.0 \\
\hline DK & Danish National Survey of Dietary Habits and PA [28] & $2000-2002$ & $7 \mathrm{dDR}$ & 1,283 & $213 \pm 74$ & 6.3 & 1,486 & $175 \pm 58$ & 9.8 \\
\hline FI & National FINDIET 2007 Survey $[29,30]$ & 2007 & adj $48 \mathrm{HR}$ & 730 & $253 \pm 220$ & 24.3 & 846 & $194 \pm 121$ & 21.9 \\
\hline \multicolumn{10}{|c|}{ Elderly (age $>64$ years) } \\
\hline $\mathrm{DE}$ & German National Nutrition Survey II [31-33] & 2005-2007 & $\mathrm{DH}$ & 1,469 & $107 \pm 40$ & 43.1 & 1,562 & $97 \pm 38$ & 53.1 \\
\hline DK & Danish National Survey of Dietary Habits and PA [28] & $2000-2002$ & $7 \mathrm{dDR}$ & 165 & $194 \pm 65$ & 7.4 & 164 & $167 \pm 56$ & 11.6 \\
\hline FI & National FINDIET 2007 Survey $[29,30]$ & 2007 & adj $48 \mathrm{HR}$ & 229 & $226 \pm 94$ & 9.0 & 234 & $182 \pm 62$ & 9.3 \\
\hline IR & SLAN 2007 [34] & 2007 & FFQ & 580 & $169 \pm 74$ & 17.6 & 742 & $155 \pm 67$ & 20.6 \\
\hline \multicolumn{10}{|c|}{ Copper } \\
\hline \multicolumn{4}{|c|}{ Adults (age 19-64 years) } & \multicolumn{3}{|c|}{$\mathrm{EAR}=0.7 \mathrm{mg} /$ day } & \multicolumn{3}{|c|}{$\mathrm{EAR}=0.7 \mathrm{mg} / \mathrm{day}$} \\
\hline FI & National FINDIET 2007 Survey $[29,30]$ & 2007 & adj $48 \mathrm{HR}$ & 730 & $1.6 \pm 0.7$ & 9.9 & 846 & $1.3 \pm 0.5$ & 11.5 \\
\hline IR & SLAN 2007 [34] & 2007 & FFQ & 662 & $1.5 \pm 0.8$ & 15.9 & 717 & $1.2 \pm 0.7$ & 23.8 \\
\hline IT & INN-CA Study [35] & 1994-1996 & $7 \mathrm{dDR}$ & 660 & $1.6 \pm 0.7$ & 9.9 & 801 & $1.3 \pm 0.5$ & 11.5 \\
\hline UK & Health Survey for England [42] & $2000-2001$ & $7 \mathrm{dDR}$ & 219 & $1.4 \pm 0.7$ & 15.9 & 210 & $1.0 \pm 0.4$ & 22.7 \\
\hline \multicolumn{10}{|c|}{ Elderly (age $>64$ years) } \\
\hline FI & National FINDIET 2007 Survey $[29,30]$ & 2007 & adj $48 \mathrm{HR}$ & 229 & $1.4 \pm 0.5$ & 8.1 & 234 & $1.2 \pm 0.5$ & 15.9 \\
\hline IR & SLAN 2007 [34] & 2007 & FFQ & 580 & $1.4 \pm 0.9$ & 21.8 & 742 & $1.3 \pm 0.7$ & 19.6 \\
\hline
\end{tabular}

EAR = Estimated average requirement; DK = Denmark; FI = Finland, IT = Italy; NE = The Netherlands; SE = Sweden; IR = Ireland; DE = Germany; $\mathrm{UK}=$ United Kingdom; $\mathrm{dDR}$ = days dietary record; adj = adjusted for intraindividual variability; $\mathrm{HR}=$ hour recall; $\mathrm{DH}=$ diet history; FFQ = food frequency questionnaire.

\section{Funding}

This work was carried out within the EURRECA Network of Excellence, which is financially supported by the Commission of the European Communities, specific Research Technology and Development (RTD) Programme Quality of Life and Management of Living Resources, within the Sixth Framework Programme, contract No. 036196. The funding source had no influence on the study design, data collection, analysis, interpretation of data, writing of the report, or the decision to submit the paper for publication.

Prevalence of Inadequate Nutrient Intakes in Europe

\section{Disclosure Statement}

The authors have no conflicts of interest to report. 


\section{References}

-1 Ashwell M, Lambert JP, Alles MS, Branca F, Bucchini L, Brzozowska A, de Groot LC, Dhonukshe-Rutten RA, Dwyer JT, Fairweather-Tait S, Koletzko B, Pavlovic M, Raats MM, Serra-Majem L, Smith R, van Ommen B, Veer P, von Rosen J, Pijls LT, EURRECA Network: How we will produce the evidence-based EURRECA toolkit to support nutrition and food policy. Eur J Nutr 2008;47(suppl 1):2-16.

$\checkmark 2$ Román-Viñas B, Serra-Majem L, Ribas-Barba L, Ngo J, García-Alvarez A, Wijnhoven TM, Tabacchi G, Branca F, de Vries J, de Groot LC: Overview of methods used to evaluate the adequacy of nutrient intakes for individuals and populations. Br J Nutr 2009; 101(suppl 2):S6-S11.

-3 Tabacchi G, Wijnhoven TM, Branca F, Román-Viñas B, Ribas-Barba L, Ngo J, García-Alvarez A, Serra-Majem L: How is the adequacy of micronutrient intake assessed across Europe? A systematic literature review. Br J Nutr 2009;101(suppl 2):S29-S36.

4 Al-Tahan J, González-Gross M, Pietrzik K: $\mathrm{B}$-vitamin status and intake in European adolescents: a review of the literature. Nutr Hosp 2006;21:452-465.

5 Fabian E, Elmadfa I: Nutritional situation of the elderly in the European Union: data of the European Nutrition and Health Report 2004. Ann Nutr Metab 2008;52(suppl 1):S57S61.

6 World Health Organization: WHO STEPS surveillance manual: the WHO STEPwise approach to chronic disease risk factor surveillance. 2005. http://www.who.int/chp/ steps (accessed September 2010).

$\checkmark 7$ De Henauw S, Brants HA, Becker W, KaicRak A, Ruprich J, Sekula W, Mensink GB, Koenig JS, EFCOSUM Group: Operationalization of food consumption surveys in Europe: recommendations from the European Food Consumption Survey Methods (EFCOSUM) Project. Eur J Clin Nutr 2002; 56(Suppl 2):S75-S88.

8 EFCOVAL: European Food Consumption Validation. 2006. http://www.efcoval.eu/ (accessed October 2010).

9 World Health Organization: WHO European Action Plan for Food and Nutrition Policy 2007-2012. Geneva, WHO, 2008.

- 10 Blanquer M, García-Alvarez A, Ribas-Barba L, Wijnhoven TM, Tabacchi G, Gurinovic M, Serra-Majem L: How to find information on national food and nutrient consumption surveys across Europe: systematic literature review and questionnaires to selected country experts are both good strategies. Br J Nutr 2009;101(suppl 2):S37-S50.

-11 Elmadfa I: European Nutrition and Health Report 2009. Forum Nutr 2009;62:1-405.
2 Flynn A, Hirvonen T, Mensink GB, Ocké MC, Serra-Majem L, Stos K, Szponar L, Tetens I, Turrini A, Fletcher R, Wildemann $\mathrm{T}$ : Intake of selected nutrients from foods, from fortification and from supplements in various European countries. Food Nutr Res 2009;53:5-10.

13 Institute of Medicine: Dietary Reference intakes: Applications in Dietary Assessment. Washington, National Academies Press, 2000.

14 Carriquiry AL: Assessing the prevalence of nutrient inadequacy. Public Health Nutr 1999;2:23-33.

15 Dodd KW, Guenther PM, Freedman LS, Subar AF, Kipnis V, Midthune D, Tooze JA, Krebs-Smith SM: Statistical methods for estimating usual intake of nutrients and foods: a review of the theory. J Am Diet Assoc 2006; 106:1640-1650.

16 Hoffmann K, Boeing H, Dufour A, Volatier JL, Telman J, Virtanen M, Becker W, De Henauw S, EFCOSUM Group: Estimating the distribution of usual dietary intake by short-term measurements. Eur J Clin Nutr 2002;56(suppl 2):S53-S62.

$\checkmark 17$ Carroll RJ, Freedman LS, Hartman AM: Use of semiquantitative food frequency questionnaires to estimate the distribution of usual intake. Am J Epidemiol 1996;143:392404.

18 Liu K: Statistical issues related to semiquantitative food-frequency questionnaires. Am J Clin Nutr 1994;59(suppl 1):262-265.

19 Serdula MK, Alexander MP, Scanlon KS, Bowman BA: What are preschool children eating? A review of dietary assessment. Annu Rev Nutr 2001;21:475-498.

20 Bingham SA, Gill C, Welch A, Day K, Cassidy A, Khaw KT, Sneyd MJ, Key TJ, Roe L, Day NE: Comparison of dietary assessment methods in nutritional epidemiology: weighed records v. $24 \mathrm{~h}$ recalls, food-frequency questionnaires and estimated-diet records. Br J Nutr 1994;72:619-643.

21 Murphy SP, Guenther PM, Kretsch MJ: Using the dietary reference intakes to assess intakes of groups: pitfalls to avoid. J Am Diet Assoc 2006;106:1550-1553.

22 Doets EL, de Wit LS, Dhonukshe-Rutten RA, Cavelaars AE, Raats MM, Timotijevic L, Brzozowska A, Wijnhoven TM, Pavlovic M, Totland TH, Andersen LF, Ruprich J, Pijls LT, Ashwell M, Lambert JP, van 't Veer P, de Groot LC: Current micronutrient recommendations in Europe: towards understanding their differences and similarities. Eur J Nutr 2008;47(suppl 1):S17-S40.

23 Nordic Council of Ministers: Nordic Nutrition Recommendations 2004: Integrating Nutrition and Physical Activity, ed 4. Copenhagen, Norden, 2004.

24 Institute of Medicine: Dietary Reference Intakes for Calcium and Vitamin D. Washington, National Academies Press, 2011.
25 Cavelaars AE, Doets EL, Dhonukshe-Rutten RA, Hermoso M, Fairweather-Tait SJ, Koletzko B, Gurinović M, Moreno LA, Cetin I, Matthys C, van 't Veer P, Ashwell M, de Groot CP: Prioritizing micronutrients for the purpose of reviewing their requirements: a protocol developed by EURRECA. Eur J Clin Nutr 2010;64(suppl 2):S19-S30.

26 Elmadfa I, Weichselbaum E, König J, de Winter A-M R, Trolle E, Haapala I, Uusitalo U, Mennen L, Hercberg S, Wolfram G, Trichopoulou A, Naska A, Benetou V, Kritsellis E, Rodler I, Zajkás G, Branca F, D’Acapito P, Klepp KI, Ali-Madar A, De Almeida MD, Alves E, Rodrigues S, Sarra-Majem L, Roman B, Sjöström M, Poortvliet E, Margetts B: European Nutrition and Health Report 2004. Forum Nutr 2005;58:1-220.

27 De Vriese S, Huybrechts I, Moreau M, van Oyen H: De Depot No. D/2006/2505/17, IPH/EPI Reports No. 2006-016. Brussels, Scientific Institute of Public Health/Epidemiology Unit, 2006.

28 Lyhne N, Christensen T, Groth MV, Fagt S, Biltoft-Jensen A, Hartkopp H, Hinsch HJ, Matthiessen J, Møller A, Saxholt E, Trolle E: Danskernes kostvaner 2000-2002 - Hovedresultater [Dietary habits of Denmark 2000-2002]. Søborg, Danmarks Fødevareforskning, 2005.

29 Paturi M, Tapanainen H, Reinivuo H, Pietinen P: The National FINDIET 2007 Survey. Helsinki, National Public Health Institute B23/2008, 2008.

30 Peltonen M, Harald K, Männistö S, Saarikoski L, Peltomäki P, Lund L, Sundvall J, Juolevi A, Laatikainen T, Aldén-Nieminen H, Luoto R, Jousilahti P, Salomaa V, Taimi M, Vartiainen E: The National FINRISK 2007 Study. Helsinki, National Public Health Institute, 2008, B34/2008.

31 Max Rubner-Institut (eds): Nationale Verzehrsstudie II. Ergebnisbericht Teil 1. Die bundesweite Befragung zur Ernährung von Jugendlichen und Erwachsenen. Karlsruhe, 2008a.

32 Max Rubner-Institut (eds): Nationale Verzehrsstudie II. Ergebnisbericht Teil 2. Die bundesweite Befragung zur Ernährung von Jugendlichen und Erwachsenen. Karlsruhe, 2008 b.

33 Max Rubner-Institut (eds): Nationale Verzehrsstudie II. Ergänzungsband zum Ergebnisbericht Teil 1. Karlsruhe, 2008c.

34 Harrington J, Perry I, Lutomski J, Morgan K, McGee H, Shelley E, Watson D, Barry M: SLÁN 2007: Survey of Lifestyle, Attitudes and Nutrition in Ireland. Dietary Habits of the Irish Population, Department of Health and Children. Dublin: The Stationery Office, 2008. 
-35 Turrini A, Saba A, Perrone D, Cialfa E, D'Amicis A: Food consumption patterns in Italy: the INN-CA Study 1994-1996. Eur J Clin Nutr 2001;55:571-588.

36 Serra Majem L, Ribas Barba L, Salvador Castell G, Castell Abat C, Román Viñas B, Serra Farró J, et al: Avaluació de l'estat nutricional de la població catalana 2002-2003. Evolució dels hàbits alimentaris i dels consum d'aliments i nutrients a Catalunya (1992-2003). Barcelona, Departament de Salut, Generalitat de Catalunya, 2006 (www.gencat.net).

37 Serra Majem L, Ribas Barba L (eds): Trends in Nutrition Status in Catalonia, Spain (1992-2003). Public Health Nutr 2007;10: 1339-1414.

-38 Serra Majem L, Ribas Barba L, Salvador Castell G, Roman Viñas B, Castell Abat C, Cabezas Peña C, Pastor Ferrer MC, Raidó Quintana B, Ngo de la Cruz J, García Alvarez A, Serra Farró J, Salleras Sanmartí L, Taradach Antoni P: Trends in the nutritional status of the Spanish population: results from the Catalan nutrition monitoring system (19922003). Rev Esp Salud Publica 2007;81:559570.

39 Becker W, Pearson M: Riksmaten 1997-98. Dietary Habits and Nutrient Intake in Sweden 1997-98 (in Swedish/English summary). Uppsala, Livsmedelsverket, 2002.

40 Hulshof KFAM, Ocke MC, van Rossum CTM, Buurma-Rethans EJM, Brants HAM, Drijvers JJMM, et al: Resultaten van de voedselconsumptiepeiling 2003. Results of the National Food Consumption Survey 2003. RIVM report 350030002; 2004 (in Dutch). Bilthoven, The Netherlands: National Institute for Public Health and the Environment.

41 Ocké MC, Hulshof KFAM, van Rossum CTM: The Dutch National Food Consumption Survey 2003. Methodological issues. Arch Public Health 2005;63:227-241.

42 Henderson L, Irving K, Gregory J, Bates CJ, Prentice A, Swan G, Farron M: The National Diet and Nutrition Survey: Adults Aged 19 to 64 Years. Volume 3: Vitamin and Mineral Intake and Urinary Analyses. London: The Stationery Office, 2003.
43 Katsouyanni K, Rimm EB, Gnardellis C, Trichopoulos D, Polychronopoulos E, Trichopoulou A: Reproducibility and relative validity of an extensive semi-quantitative food frequency questionnaire using dietary records and biochemical markers among Greek schoolteachers. Int J Epidemiol 1997;26(suppl)1:118-127.

44 Harrington J: Validation of a Food Frequency Questionnaire as a Tool for Assessing Nutrient Intake; PhD thesis, National University of Ireland, Dublin, 1997.

45 Andersen LF, Solvoll K, Johansson LR, Salminen I, Aro A, Drevon CA: Evaluation of a food frequency questionnaire with weighed records, fatty Acids, and alpha-tocopherol in adipose tissue and serum. Am J Epidemiol 1999; 150:75-87.

46 Ramos E: Health Determinants in Porto Adolescents; PhD thesis, University of Porto, Porto, 2006.

47 Lopes C, Oliveira A, Santos AC, Ramos E, Gaio AR, Severo M, Barros H: Consumo alimentar no Porto 2006. http://www.consumoalimentarporto.med.up.pt (accessed July 22, 2011).

48 Mensink GB, Haftenberger M, Thamm M: Validity of DISHES 98, a computerised dietary history interview: energy and macronutrient intake. Eur J Clin Nutr 2001;55: 409-417.

49 Allen L, de Benoist B, Dary O, Hurrell R Guidelines on Food Fortification with $\mathrm{Mi}$ cronutrients. Geneva, WHO/FAO, 2006

50 Katamay SW, Esslinger KA, Vigneault M, Johnston JL, Junkins BA, Robbins LG, Sirois IV, Jones-Mclean EM, Kennedy AF, Bush MA, Brulé D, Martineau C: Eating well with Canada's Food Guide (2007): development of the food intake pattern. Nutr Rev 2007;65: 155-166

-51 Poslusna K, Ruprich J, de Vries JH, Jakubikova $M$, van't Veer P: Misreporting of energy and micronutrient intake estimated by food records and $24 \mathrm{~h}$ recalls, control and adjustment methods in practice. Br J Nutr 2009; 101(suppl 2):S73-S85.

52 Skeie G, Braaten T, Hjartåker A, Lentjes M, Amiano P, Jakszyn P, Pala V, Palanca A, Niekerk EM, Verhagen H, Avloniti K, Psaltopoulou T, Niravong M, Touvier M, Nimptsch K, Haubrock J, Walker L, Spencer EA Roswall N, Olsen A, Wallström P, Nilsson S, Casagrande C, Deharveng G, Hellström V, Boutron-Ruault MC, Tjønneland A, Joensen AM, Clavel-Chapelon F, Trichopoulou A Martinez C, Rodríguez L, Frasca G, Sacerdote $\mathrm{C}$, Peeters $\mathrm{PH}$, Linseisen J, Schienkiewitz A, Welch AA, Manjer J, Ferrari P, Riboli E, Bingham S, Engeset D, Lund E, Slimani N: Use of dietary supplements in the European Prospective Investigation into Cancer and Nutrition calibration study. Eur J Clin Nutr 2009;63(suppl 4):226-238.
53 Burnett-Hartman AN, Fitzpatrick AL, Gao K, Jackson SA, Schreiner PJ: Supplement use contributes to meeting recommended dietary intakes for calcium, magnesium, and vitamin $\mathrm{C}$ in four ethnicities of middle-aged and older Americans: the Multi-Ethnic Study of Atherosclerosis. J Am Diet Assoc 2009; 109:422-429.

54 Hannon EM, Kiely M, Flynn A: The impact of voluntary fortification of foods on micronutrient intakes in Irish adults. Br J Nutr 2007;97:1177-1186.

55 Sebastian RS, Cleveland LE, Goldman JD, Moshfegh AJ: Older adults who use vitamin/ mineral supplements differ from nonusers in nutrient intake adequacy and dietary attitudes. J Am Diet Assoc 2007;107:1322-1332.

$\checkmark 56$ Bailey RL, Dodd KW, Gahche JJ, Dwyer JT, McDowell MA, Yetley EA, Sempos CA, Burt VL, Radimer KL, Picciano MF: Total folate and folic acid intake from foods and dietary supplements in the United States: 20032006. Am J Clin Nutr 2010;91:231-237.

57 Moshfegh A, Goldman J, Cleveland L: What we eat in America - NANHES 2001-2002: usual nutrient intakes from food compared to dietary references intake. Washington, US Department of Agriculture, Agricultural Research Service, 2005.

58 Health Canada, Statistics Canada: Canadian Community Health Survey - cycle 2.2, nutrition (2004): nutrient intakes from food provincial, regional and national data. Ottawa, Health Canada, 2009.

59 Cade J, Thompson R, Burley V, Warm D: Development, validation and utilisation of food-frequency questionnaires - a review. Public Health Nutr 2002;5:567-587.

60 Sevak L, Mangtani P, McCormack V, Bhakta D, Kassam-Khamis T, dos Santos Silva I: Validation of a food frequency questionnaire to assess macro- and micro-nutrient intake among South Asians in the United Kingdom. Eur J Nutr 2004;43:160-168.

61 Murphy SP: Using the new dietary reference intakes to assess diets: a map to the maze. Nutr Rev 2002;60:267-275.

62 Lauzon B, Volatier JL, Martin A: A Monte Carlo simulation to validate the EAR cutpoint method for assessing the prevalence of nutrient inadequacy at the population level. Public Health Nutr 2004;7:893-900. 